\title{
Econometric Model to Estimate Defaults on Payment in the Spanish Financial Sector in Oliver Wyman's Stress Tests
}

\author{
Salvador Climent-Serrano \\ Correspondence: Salvador Climent-Serrano, Department of Financial and Actuarial Economics. Faculty of Economics, \\ Campus Els Tarongers, Valencia, Zip code 46022, Spain.
}

Received: September 1, 2016

Accepted: September 14, 2016

Available online: October 6, 2016

doi:10.11114/afa.v3i1.1853

URL: http://dx.doi.org/10.11114/afa.v3i1.1853

\begin{abstract}
This work develops an econometric model based on the exogenous economic variables used in Oliver Wyman's report. In this case the model is used in order to estimate late payments (NPLs) by Spanish credit entities. A model based on variables considered to be optimal to quantify impact on the NPLs is developed by studying the aforementioned variables, modifying them and eliminating any which are superfluous. Furthermore, whether or not the model is optimal for long periods of time is corroborated. This is due to the fact that the scenario in Oliver Wyman's report from September 2012 (Wyman 2012) is based on 30 years of Spanish economical historical data, as stated in the report itself.

The results indicate the variables that have impact on defaults. The increase in housing prices, the Madrid Stock Exchange Index, the Exchange Rate the euro against USD. The Euribor 12 months and the industries Credit to other residents, decreases the delinquency. The NPLs also fell by transfers from riskier assets to SAREB. However, these results are different if the economy is growing or in recession. So the results will not be optimal but the appropriate model is employed.
\end{abstract}

Keywords: economic cycle, NPLs, Spanish banks, housing prices, unemployment, delinquency

JEL Codes: G21; G32; G17

\section{Introduction}

"The stress tests, tailored to the situation at hand, can provide clarity by openly disclosing details of the results and approaches taken, allowing trust to be regained." (Schuermann, 2014) This is the answer provided by Til Schuerman Management Consulting firm Oliver Wyman and Company to the question "how much capital and liquidity does a bank need to support its risk taking activities? During the recent (and still ongoing) financial crisis". Given that, according to the investigator, the standard approaches, such as regulatory capital ratios, were no longer credible, and that he bank balance sheets are notoriously opaque and susceptible to asset substitution of high risk for low risk assets.

However the reliability of the stress tests is not guaranteed and even with the latest techniques errors can be significant. For example, in the Spanish case of Bankia The European Banking Authority (EBA), published a statement the day it finished the Initial Public Offering (IPO) of Bankia in which it stated that based on the 2011 European stress test for the adverse scenario in 2012 the BFA-Bankia group would surpass the minimum capital threshold before the IPO. This means not only that the initial situation met the capital requirements the but also that the IPO would allow for substantial improvement. However between 2011 and 2012 the organization suffered losses of more than 26,000 million euros and carried out an expansion of its capital with public funds of more than 22,500 million euros. Furthermore, according to Climent and Pavía (2015) one share in which the IPO had a price of $€ 3.75$ and the beginning of 2013 was traded at 0,006 euros.

Moreover, with the same entity, BFA-Bankia, one year after the Oliver Wyman report, which was published on the 28th September 2012, (Wyman, 2012). The EBA, estimated a profit before the provisions, impairment losses on assets and the taxes for all three years (2012 - 2014) of approximately 163 million euro profit in the base scenario and of 2.236 million euros in losses in the adverse scenario and however, the results were 5.388 million profit.

Another inconvenience is that which is noted by Cerutti, and. Schmieder (2014), these writers express that the stress tests run at the group level using "only" consolidated data and do not take into account the possibility that home or host regulators might limit or even fully block flows within banking groups. 
However stress tests are being used more and more frequently in order to evaluate the solvency of credit organizations. They have been extensively used by banks with international activity since 1990. Regulators and bank supervisors require them in order to monitor risks in the market and credit (Buraschi, 2014). Today, with improved technology, risk estimates can be made quickly, accurately and without having to rely solely on human judgment. In addition, credit institutions must allocate their capital an optimal manner so that the most efficient investments can be made (Boran, 2011).

The stress tests macro are more recent and are used as an instrument in order to evaluate the vulnerability of complete financial systems. They have been an important component of the Financial Sector Assessment Programs (FSAPs) launched by the IMF and the World Bank in the late 1990's and at this moment in time have become a common tool used to evaluate financial stability by policy makers (Sorge 2004).

Risk management as a technical discipline came into its own with the publication of the Risk Metrics technical document in 1994, along with stress testing of two kinds, sensitivities and scenarios (Schuermann 2014). In the 1990s policymakers, researchers, and practitioners became interested in better understanding vulnerabilities in financial systems. In response to this demand, and as a consequence of the increased financial instability in many countries, stress tests (Čihák, 2007) were used, and based on Basilea's rules their use was generalized Schuermann (2014).

The need for capital as detected by the stress tests is the result of combining two principle variables: a) expected losses of granted credit and b) the capacity to absorb the aforementioned losses. The data used varies, although it is generally quite similar, e.g. the last stress tests on the Spanish financial system (Wyman, 2012) are a combination of information of: accountancy in the organizations, the central banking database, audit analyses, the valuations of executed mortgage assets and the estimation of macro economical data (Gutiérrez-López, and Abad-González, 2014).

However, and above all in the latest models, a section of the methodology is not made public, most of all with reference to the impact of economic variables in the different asset type of the organizations (Buncic, and Melecky, 2013).

Stress tests cannot serve as a strategy for businesses if the provisional losses are not probable (Basu 2013). This why there is currently a substantial interest in the connection between macroeconomics and microeconomics in the financial sector. This has lead professionals to use regression techniques in order to link the Non-Performing Loans (NPLs) provisions for insolvency or the probability of non-payment to macroeconomic fundamentals in a more explicit manner (Sorge, 2004 and Foglia, 2009). In this paper a regression model by OLS is used for the forecast, this means that the impact of each economic variable on NPLs is included and therefore the impact on expected losses is also included. According to Pérez-Cárceles et al (2016) these models are appropriate for the aim of this study

The objective of this paper is to construct an econometric model in order to estimate one of the two principle variables of stress tests: expected losses in granted credit. In concrete the model will estimate the impact of economic variables on NPLs given that loan-loss provisioning depends on NPLs. The model is an estimation for Spain seeing as the singular circumstances of each country can greatly influences the results of the parameters Alamá et al (2015). Although the model is exportable to any country by adapting the regression to each particular circumstance in order to obtain new coefficients.

The NPLs are the most important variable, which affects loss in stress tests. Other authors even suggest putting a maximum on the NPLs. Incentives to increase risk and reduce cost exist in credit entities exist, something which will decrease the evaluation of risk and increase the NPLs (Wang and Huang 2007).

The methodology used is the construction of an econometric model with eight variables. The data comes from the databases of the Bank of Spain, the National Institute of Statistics and the Ministry of Development and cover a period of 15 years. The Least Squares Method is used with very good result, above all in relation to prediction, with R-squared adjusted to above $90 \%$.

This work contributes to research by providing an improvement in the estimation of the impact of economic variables on NPLs and an improvement on the estimation of losses in stress tests for the financial sector.

\subsection{Background}

NPLs are not only one of the most important factors in any financial system there are also the most volatile. In Spain, which is the focus of this paper, volatility has been much greater in recent times. In 2007 NPLs were lower than $1 \%$ and in 2013 there were near 14\% (Climent and Pavía, 2014a). However in the first phase studied in this paper the evolution of NPLs was very stable. For nearly the whole period from 2000 to 2007 the NPLs remained at below 1\%. It is for this reason that the period of time covered by this study considers two very different phases, i) a phase of stability, with a low rate of NPLs and ii) a turbulent phase with a high rate of NPLs. During the second period some Spanish credit entities required a large amount of support from public funds (Climent and Pavía, 2014b). NPLs are a common trigger of financial crises. In the 80s and 90s authors such as Demirguc-Kunt, (1989); Whalen, (1991) and Barr and Siems 
(1994) agreed that all cases of bank failure have a large proportion of NPLs.

The rest of this paper, after the introduction, will continue in the following manner: in point two there will be a brief literature review, in point three the material and methods will be presented, point four will give the results, point five will include a brief discussion and the paper ends with the conclusions in point six.

\section{Literature Review}

The stress test the Bank of Spain of 2012 developed by Oliver Wyman was made according to the agreement on the Memorandum of Understanding adopted on 20 July 2012 between the Spanish and European authorities.

In the stress test was evaluated at fourteen major Spanish banking groups representing around $90 \%$ of the assets of the Spanish banking system. According to the stress test capital needs for the Spanish banking system were 60,000 million euros.

\subsection{Determinants of NPLs}

There is quite a lot of literature about what determines NPLs, including some of the following:

Results obtained by Berger and De Young (1997) suggest that NPLs precede reductions in efficiency, whilst reductions of bank capital precede increases in NPLs. The study took place in banks in the USA in the period of 1985-1994. It made use of variables such as: NPLs, efficiency, equity capital, risk-weighted asset and the location of the credit entities. Asmild and Matthews (2012) agreed that state owned banks are less efficient on NPLs than joint stock banks in China.

Ghosh (2005) examined the link between leverage and NPLs in India during the period 1993-2004. The results suggest that leverage is an important factor in determining NPLs. In order to discover this they used variables such as: equity capital, risk-weighted assets, return on asset; operating expenses, wholesale price index, real cost of capital, real GDP growth rate, real growth rate of broad money, real growth rate of domestic credit; real effective exchange rate; sector leverage and return on net worth.

Podpiera and Weill (2008) studied whether or not bad management increases NPLs, and as a result bankruptcy in the banks with the following variables: loans granted, investment assets, expenses for employees, other expenses, interest expenses and non-performing loans. Festić et al (2011) analysed the relation between NPLs and the weakness of the banking sector using the following variables: NPLs, deposits, loan, net foreign assets, foreign direct investment, export of goods and services, gross fixed capital formation, compensation of employees, market concentration, deposits relative to GDP, risk weighted assets, non-earning assets, banking sector development index, net interest margin.

As is shown in the literature review the majority of the models used to study defaults on payment by credit entities use both internal and external variables. However stress tests only make use of external variables, both macroeconomic and microeconomic. Although the majority of reports designate the surrounding or scenario as macroeconomics they also include some microeconomic variables such as the cost of housing, etc. (Wyman 2012).

Stress tests study the impact of macroeconomic scenarios on the assets of the credit entities. Therefore there is a radical change of structure in respect to the previously seen studies. In these cases the assets are what determine NPLs. The external variables used in the previous investigations coincide with those used in the stress tests.

\subsection{External Variables in Stress Tests}

Stress tests are a common tool in risk management in order to assess the potential impact of economic changes that can affect the financial sector (Huang, Zhou, and Zhu 2009; Coffinet, Pop, and Tiesset, 2013; Bellini 2013; Cerutti, and Schmieder 2014).

Various different methods are used for stress tests. In the report entitled "Stress Testing at Major Financial Institutions: Survey Results and Practices," published by the Committee on the Global Financial System, some of the different types of scenario are demonstrated. According to Abdymomunov and Gerlach (2014) these scenarios can be classed as historical scenarios and hypothetical scenarios. Historical scenarios are based on either (i) risk factors from specific historical events or (ii) extreme changes in the risk factors over a period of time. Hypothetical scenarios can be (i) deterministic, in which some key risk scenarios are hypothetically assumed, or (ii) stochastic, where a large number of hypothetical scenarios are randomly generated (Alessi, et al 2014). The report by Oliver Wyman (Wyman 2012) would be an example of an historical scenario.

\subsubsection{Variables}

With respect to the variables used, an investigation by Ju et all (2015) in Korea which covers the period from 1999 to 2004 uses 7 macroeconomic variables: monthly change rate of KOSPI (Korean Composite Stock Price Index), the operation index of SMEs, The CPI (Consumer Price Index), the three-year earnings rate of national bonds, the won-to-dollar exchange rate, GDP growth rate, and Unemployment rate. 
In their investigation Buncic and Melecky (2013) use 5 variables: NPLs ratio ( $t$-1), GDP growth, inflation, lending rate and the change in the nominal exchange rate. The estimates were calculated with the Arellano and Bond estimator. In this case NPLs are incorporated with a delay of one year. By including this as an explanatory variable the reliability of the model is improved, although information is lost. By using the dependent variable with a one year delay as an explanatory variable information from the rest of the variables is included.

2.2.2 NPLs

The analysis of NPLs is an important subject related to the management of loan portfolios (Jakubik, 2007). With respect to the effect of the variables on NPLs, the result of the investigation by Ju et al (2015) reflected the consumer price index, the won-to dollar exchange rate and market potential that have a positive sign on the NPLs.

The initial investigations already suggested a strong relationship between macroeconomic evolution and the leverage of businesses and amongst these the probability of financial crises (Rajan and Zingales, 1995). The inverse relation between NPLs and capital has by widely documented at an international level by Kwan and Eisenbis (1997); Rime, (2001) and Das and Ghosh (2004).

\subsubsection{Macro-Prudential Stress Testing}

Recent examples of macro-prudential stress testing

The US bank stress test in 2009, the Supervisory Capital Assessment Program or SCAP (Board of Governors of the Federal Reserve System 2009). 19 banks were examined, ten of the 19 banks were required to raise a total of $\$ 75.000$ million in capital within six months.

In Europe the Committee of European Bank Supervisors (CEBS) conducted a stress test of 91 European banks in 2010, covering about two-thirds of the total European bank assets. The stress test included imposing haircuts on the market value of sovereign bonds held in the trading book. Of the 91 banks, only seven didn't fulfill the required conditions, the macroeconomic scenarios included the following variables: GDP at constant prices, unemployment, short-term interest rates, long-term interest rates, nominal USD exchange rate and CPI (CEBS, 2010).

In 2011 macro-prudential stress testing was once again undertaken, in this case by the EBA, which covered 90 banks in 21 countries with results similar to those from the previous year. Five of the 25 Spanish banks in the EBA stress test did not pass, though. Entities such as Bankia or Novacaixa Galicia which had previously audited and needed public help did pass the test. The main macroeconomic variables used were GDP, unemployment and house prices (EBA 2011).

The third case of macro-prudential stress testing was carried out in Spain where three stress tests were completed. First was the IMF's Financial Sector Assessment Program (FSAP), conducted jointly with the Bank of Spain. The results of this were that 10 with 11 of the 29 banks requiring a total of 17,700 millions euros capital (4\% core Tier 1 capital), or 17 banks requiring a total of 37,100 millions euros (7\% core Tier 1 capital). The variables used were: real GDP, unemployment rate, Madrid stock exchange index, credit to other resident sectors (households and non-financial firms) This data was published on $8^{\text {th }}$ June 2011 (International Monetary Fund 2012). Second was a short top-down exercise conducted by two outside advisers (Roland Berger and Oliver Wyman), and those results were released with only an overall capital need. The results were released on $21^{\text {st }}$ June (Berger 2012 and Wyman 2012). The variables used in these scenarios were: real GDP, GDP deflator, nominal GDP, harmonized index of consumer prices, unemployment rate, exchange rate against USD, Madrid stock exchange index, credit to other resident sectors (households and non-financial firms), long-term interest rates (Spanish debt, 10 years), short-term interest rate (Euribor, 3 months), Euribor, 12 months, house/land prices (commercial property and residential property). The third was a more detailed and intensive bottom-up analysis by Oliver Wyman, with results released on $28^{\text {th }}$ September, 2012, showing that 7 of 14 the banking groups needed a total of 57,300 million de euros using the post-stress core Tier 1 threshold of $6 \%$. This was completed using the same variables as in the Macroeconomic scenarios.

\section{Materials and Methods}

The dependent variable is the NPLs. The independent variables initially chosen are those used in Oliver Wyman's 2012 stress tests in Spain. In this way the model is adjusted, at least in part, to the variables studied in the literature review. Moreover, the effect will be verified in a stress test which has already been presented.

The data of the dependent variable NPLs are quarterly data published by the Bank of Spain for all Spanish banks.

The variables are: real GDP, GDP deflator, nominal GDP, harmonized Index of consumer prices, unemployment rate, exchange rate against USD, Madrid stock exchange index, credit to other resident sectors (households and non-financial firms), long-term interest rates (Spanish debt, 10 years), short-term interest rate (Euribor, 3 months), Euribor, 12 months, house and land prices (commercial property and residential property). The impact will be determined by the coefficient sign of the regression of the variables. The descriptive statistics of the variables are shown in Table 1. 
Table 1. Descriptive statistics of the explanatory variables

\begin{tabular}{|c|c|c|c|c|c|c|c|c|c|c|c|c|c|c|c|}
\hline & $\frac{n}{\bar{z}}$ & 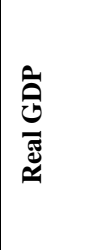 & 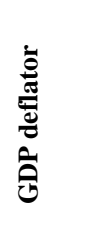 & 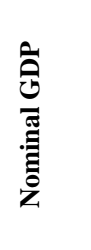 & 它 & 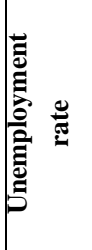 & 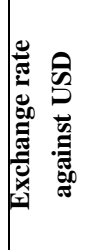 & 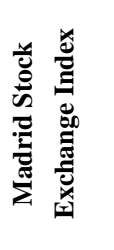 & 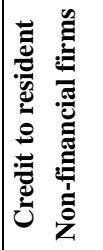 & 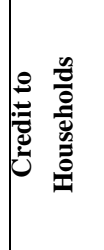 & 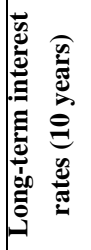 & 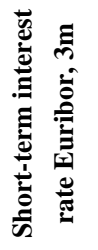 & 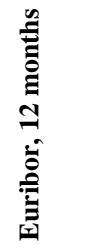 & 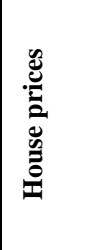 & 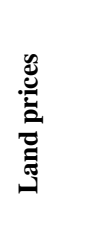 \\
\hline Mean & $6.30 \%$ & $-0.13 \%$ & $-1.86 \%$ & $0.81 \%$ & $2.3 \%$ & $18.6 \%$ & 1.37 & $0.78 \%$ & $-0.08 \%$ & $0.25 \%$ & $4.5 \%$ & $1.8 \%$ & $2.17 \%$ & $-3.49 \%$ & $-7.03 \%$ \\
\hline Median & $5.42 \%$ & $-0.10 \%$ & $-1.19 \%$ & $0.10 \%$ & $2.5 \%$ & $19.9 \%$ & 1.34 & $-1.89 \%$ & $-0.47 \%$ & $-0.12 \%$ & $4.4 \%$ & $1.0 \%$ & $1.50 \%$ & $-4.49 \%$ & $-7.76 \%$ \\
\hline Maximum & $13.77 \%$ & $4.00 \%$ & $1.69 \%$ & $7.90 \%$ & $4.5 \%$ & $26.9 \%$ & 1.56 & $41.70 \%$ & $7.22 \%$ & $5.24 \%$ & $6.6 \%$ & $5.3 \%$ & $5.50 \%$ & $7.24 \%$ & $8.58 \%$ \\
\hline Minimum & $0.63 \%$ & $-4.50 \%$ & $-17.6 \%$ & $-4.6 \%$ & $-0.2 \%$ & $7.9 \%$ & 1.22 & $-42.12 \%$ & $-9.72 \%$ & $-1.84 \%$ & $2.7 \%$ & $0.2 \%$ & $0.49 \%$ & $\begin{array}{c}-10.02 \\
\%\end{array}$ & $\begin{array}{c}-21.09 \\
\%\end{array}$ \\
\hline Std. Dev. & $4.27 \%$ & $2.31 \%$ & $3.48 \%$ & $3.47 \%$ & $1.2 \%$ & $6.5 \%$ & 0.08 & $23.48 \%$ & $3.39 \%$ & $1.84 \%$ & $0.8 \%$ & $1.7 \%$ & $1.66 \%$ & $4.77 \%$ & $8.22 \%$ \\
\hline
\end{tabular}

Own elaboration

\subsection{Methods}

The first model was estimated by the least squares method using the statistical package software EViews versión 7 . The sample covers the period from the last trimester of 2006 to the second of 2014, Model 1-, see Table 3.

$N P L s_{t}=\beta_{1}+\beta_{2}$ Real GDP $t+\beta_{3}$ GDP deflator d $_{t}+\beta_{4}$ Nominal GDP $_{t}+\beta_{5}$ HICP $_{t}+\beta_{6}$ Unemployment $_{t}+$

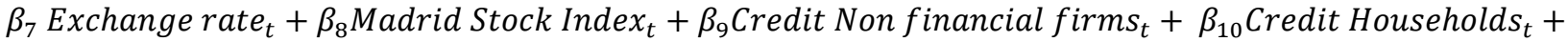
$\beta_{11}$ Long term interest $_{t}+\beta_{12}$ Euribor, $12 m_{t}+\beta_{13}$ Euribor, $3 m_{t}+\beta_{14}$ House prices $_{t}+\beta_{15}$ Land prices $_{t}+$ $\varepsilon_{t} \quad \ldots \quad$ Model 1

The result of $\mathrm{R}$ - squared adjusted is good, 0.974. However, the Ramsey Reset Test show specification problems in the functional form. Furthermore the majority of the descriptive statistics are not statistically significant, see Table 3 . High correlation between some of the descriptive variables are also detected, see Table 2.

From the study of the correlation and of the characteristics of the variables, we can deduce that some of the variables could be redundant. In order to detect this redundancy we apply the Redundant Variables Test in EViews, given that some of the variables inform us about very similar macroeconomic data.

Table 2. Correlation between Descriptive Variables

\begin{tabular}{|c|c|c|c|c|c|c|c|c|c|c|c|c|c|c|}
\hline Correlation & 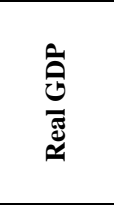 & 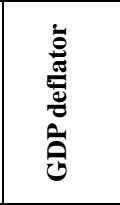 & 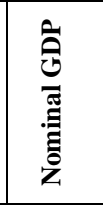 & 兰 & 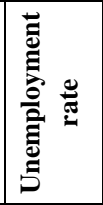 & 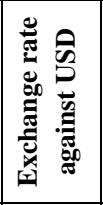 & 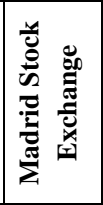 & 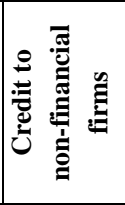 & 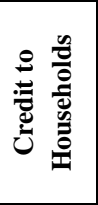 & 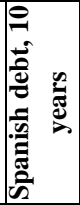 & 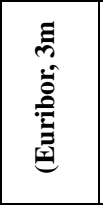 & 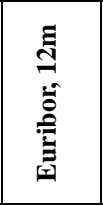 & 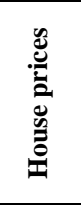 & 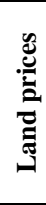 \\
\hline Real GDP & 1 & & & & & & & & & & & & & \\
\hline GDP deflator & 0.215 & 1 & & & & & & & & & & & & \\
\hline Nominal GDP & $0.827 * *$ & 0.235 & 1 & & & & & & & & & & & \\
\hline $\mathrm{HICP}$ & $0.385^{* *}$ & -0.016 & $0.36 * *$ & 1 & & & & & & & & & & \\
\hline Unemployment & $-0.504 * *$ & $-0.450 * *$ & $-0.42 * *$ & -0.288 & 1 & & & & & & & & & \\
\hline Exchange USD & 0.055 & 0.186 & 0.191 & 0.113 & $-0.44 * *$ & 1 & & & & & & & & \\
\hline M. Stock Exch. & $0.355^{*}$ & 0.013 & $0.333^{*}$ & $-0.53 * *$ & 0.106 & 0.102 & 1 & & & & & & & \\
\hline Credit firms & $0.739^{* *}$ & $0.371 * *$ & $0.66^{* *}$ & 0.285 & $-0.82 * *$ & 0.252 & 0.132 & 1 & & & & & & \\
\hline Cre. Households & $0.854 * *$ & 0.273 & $0.70^{* *}$ & 0.218 & $-0.69 * *$ & 0.201 & $0.333^{*}$ & $0.847 * * *$ & 1 & & & & & \\
\hline Spanish debt, $10 \mathrm{y}$. & -0.164 & -0.262 & -0.133 & $0.353^{*}$ & 0.241 & -0.270 & $-0.51 * *$ & -0.291 & -0.269 & 1 & & & & \\
\hline Euribor, 3m & $0.693 * *$ & $0.319^{*}$ & $0.69 * *$ & $0.63 * *$ & $-0.80 * *$ & $0.51 * *$ & -0.091 & $0.773 * * *$ & $0.71 * *$ & -0.11 & 1 & & & \\
\hline Euribor, $12 \mathrm{~m}$ & $0.682^{* * *}$ & $0.320^{*}$ & $0.68 * *$ & $0.63 * *$ & $-0.82 * *$ & $0.51 * *$ & -0.108 & $0.783 * * *$ & $0.71 * *$ & $\mid-0.07$ & $0.99 * *$ & 1 & & \\
\hline House prices & $0.306^{*}$ & 0.058 & 0.126 & $0.331 *$ & $-0.317^{*}$ & 0.093 & -0.161 & $0.357 * *$ & 0.255 & 0.298 & $0.35 * *$ & $0.37 * *$ & 1 & \\
\hline Land prices & $0.577^{* * *}$ & 0.054 & $0.40 * *$ & 0.240 & $-0.43^{* *}$ & 0.129 & 0.182 & $0.404 * *$ & $0.57 * *$ & 0.081 & $0.43 * *$ & $0.43 * *$ & 0.168 & 1 \\
\hline
\end{tabular}


The first variables to be eliminated are: nominal GDP and real GDP. The variables provide the same information. Furthermore, there is a strong correlation between them and several of the other descriptive variables. Moreover, the Redundant Variables Test indicates that these variables are redundant.

In order to substitute these two variables GDP per capita has been chosen given that it provides better information that the two previous variables. A country can increase its nominal GDP and its real GDP, and yet at the same time it's possible that its citizens do not become any richer and may even become poorer. This circumstance would appear in the case that a population increased in a greater proportion that the nominal GDP and the real GDP. However, by using the GDP per capita this circumstance is taken into account.

Of the three variables which represent types of interest two were eliminated: 1) the Long-term interest rates (Spanish debt, 10 years), was eliminated because it is redundant, according to the Redundant Variables Test. Between the Euribor, 12 months and short-term interest rate (Euribor, 3 months) the latter was eliminated because the correlation between the two variables is 0.995 and significant to $1 \%$

Credit to other resident sectors (households and non-financial firms), were correlated between each other and resulted to be redundant variables, according to the Redundant Variables Test. In this case they were both substituted for total credit to other resident sectors.

The two variables that measure inflation of the economy, the GDP deflator and harmonized index of consumer prices they are redundant according to the Redundant Variables Test, and therefore it was eliminated.

The rest of the variable did not confirm the redundant test and therefore they are used to estimate Model 2.

$$
\begin{aligned}
& N P L s_{t}=\beta_{1}+\beta_{2} G D P \text { per capita }{ }_{t}+\beta_{3} G D P \text { deflator }_{t}+\beta_{4} \text { Unemployment }_{t}+\beta_{5} \text { Madrid Stock Index }_{t}+
\end{aligned}
$$

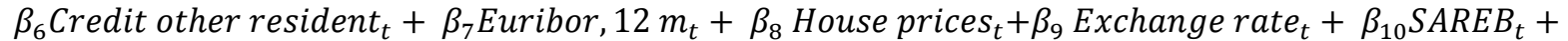

$$
\begin{aligned}
& \beta_{11} \text { Land prices }_{t}+\varepsilon_{t} \text { Model } 2
\end{aligned}
$$

The Ramsey Reset Test the Eviews, indicate that there continue to be problems in the functional form of the model. Therefore the functional form of the variables best suited to the model is investigated. The variables which were modified are Madrid stock exchange index and house prices through logarithms. The rest of the variables remain unmodified. In this case the Ramsey Reset Test confirms the optimum functional form of model 3, see Table 3 .

$$
\begin{aligned}
& N P L s_{t}=\beta_{1}+\beta_{2} \text { GDP per capita }{ }_{t}+\beta_{3} \text { GDP de } \text { flator }_{t}+\beta_{4} \text { Unemployment }_{t}+\beta_{5} \log _{-} \text {Madrid Stock Index }_{t}+
\end{aligned}
$$

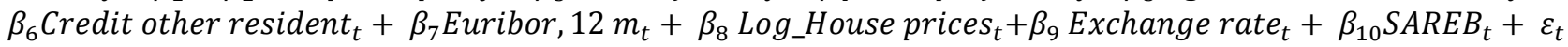

$$
\begin{aligned}
& \text { Model } 3
\end{aligned}
$$

In the last quarter of 2012 and first of 2013 is created SAREB (Management Company for Assets Arising from the Banking Sector Reorganisation) and a large amount of non-performing assets are transferred to this entity. In order to take this situation into account a dummy variable named SAREB was introduced into the model. This dummy variable has a value of in all the quarters except the fourth trimester of 2012 and the first trimester of 2013 which have a value of 1. In these two periods the majority of the "toxic assets" were transmitted to SAREB.

Distinct contrasts were made to this model in order to validate the regression. Firstly, it is confirmed the normality of the residues through the Jarque-Bera test. Not exist problems with residues autocorrelation. The Harvey Test confirms that there is no heteroskedasticity. Finally, the Durbin-Watson statistic with a value of 2.089 confirms that there is no first order correlation. The model was estimated by the White heteroskedasticity-consistent standard errors and covariance method.

\subsection{Sample}

All the models and contrasts were undertaken with a sample which covers the period from the final trimester of 2006 until the second trimester of 2014, the most recent data available. However, the scenarios in Oliver Wyman's (Wyman 2012) stress tests were estimated relative to 30 year Spanish history and relative to scenarios used in stress tests conducted in other jurisdictions. Therefore, a new model is estimated using all years available. The maximum number of available years is about 15, (from the last trimester of 2000 to the second trimester of 2014). The majority of the variables in the sources consulted, INE; Bank of Spain and Ministry of Development, did not included older data.

Upon expanding the sample from 2000q4 to 2014q2 model 4 is obtained, see Table 3.

$$
\begin{aligned}
& N P L s_{t}=\beta_{1}+\beta_{2} \text { GDP per capita } a_{t}+\beta_{3} \text { GDP deflator } \text { d }_{t}+\beta_{4} \text { Unemployment }_{t}+\beta_{5} \log _{-} \text {Madrid Stock Index }_{t}+
\end{aligned}
$$

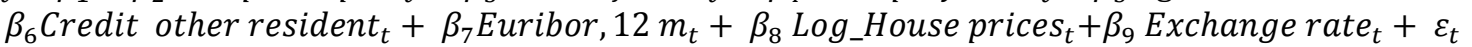

$$
\begin{aligned}
& \text { Model } 4
\end{aligned}
$$

When undertaking the tests it was observed that variables which had been significant ceased to be so. Specification problems appeared in the functional form, and moreover there is structural change. This structural change was contrasted through the Chow Breakpoint Test and Chow Forecast Test, and through the recursive residual estimates. 
These tests show that the coefficients obtained in periods of stability are different to those obtained in periods of recession. This is a very important result given that in the stress tests the same parameters are used for all scenarios and yet one should be used ad hoc for each type of situation.

\section{Results}

The variables were constructed in the following manner: real GDP and nominal GDP, rate of growth. GDP per capita, in euros. GDP deflator, rate of variation in respect to the previous year. Harmonized index of consumer prices, annual growth. Unemployment rate, annual rate of variation. Exchange rate against the USD, rate of trimester variation in the euro-dollar exchange rate. Madrid stock exchange index, variable logarithm, credit to other resident sectors non-financial firms, annual rate of variation. Long-term interest rates (Spanish debt, 10 years), interest type of Spanish treasure bonds from 10 years. Euribor, 12 months, interest type. Short-term interest rate (Euribor, 3 months), interest type. House prices, logarithm of the cost of housing in thousands of euros. Land prices, cost of land in thousands of euros.

Table 3. Econometric Regressions Models. Dependent Variable: NPLs

\begin{tabular}{|c|c|c|c|c|c|c|c|}
\hline \multicolumn{2}{|l|}{ Model 1} & \multicolumn{2}{|c|}{ Model 2} & \multicolumn{2}{|c|}{ Model 3} & \multicolumn{2}{|c|}{ Model 4} \\
\hline Variable & Coefficient & Variable & Coefficient & Variable & Coefficient & Variable & Coefficient \\
\hline \multirow{2}{*}{$\mathrm{C}$} & $-0.158 * * *$ & \multirow{2}{*}{ C } & 0.276 & \multirow{2}{*}{$\mathrm{C}$} & $2.457 * * *$ & \multirow{2}{*}{$\mathrm{C}$} & $1.550 * * *$ \\
\hline & $(0.050)$ & & $(0.399)$ & & $(0.085)$ & & $(0.124)$ \\
\hline \multirow{2}{*}{ Real GDP } & -0.131 & \multirow{2}{*}{ GDP per capita } & 0.000 & \multirow{2}{*}{ GDP per capita } & $0.000 * * *$ & \multirow{2}{*}{ GDP per capita } & $0.000 * * *$ \\
\hline & $(0.268)$ & & $(0.000)$ & & $(0.000)$ & & $(0.000)$ \\
\hline \multirow{2}{*}{ GDP deflator } & $0.002 * * *$ & \multirow{2}{*}{ GDP deflator } & -0.000 & \multirow{2}{*}{ GDP deflator } & 0.000 & \multirow{2}{*}{ GDP deflator } & 0.000 \\
\hline & $(0.000)$ & & $(0.000)$ & & $(0.000)$ & & $(0.000)$ \\
\hline \multirow{2}{*}{ Nominal GDP } & 0.394 & \multirow{2}{*}{$\begin{array}{l}\text { Unemployment } \\
\text { rate variation }\end{array}$} & -0.071 & \multirow{2}{*}{$\begin{array}{l}\text { Unemployment } \\
\text { rate variation }\end{array}$} & $0.029 * * *$ & \multirow{2}{*}{$\begin{array}{l}\text { Unemployment rate } \\
\text { variation }\end{array}$} & 0.003 \\
\hline & $(0.324)$ & & $(0.049)$ & & $(0.007)$ & & $(0.010)$ \\
\hline \multirow{2}{*}{$\begin{array}{l}\text { Harmonized Index } \\
\text { of Consumer Prices }\end{array}$} & 0.230 & \multirow{2}{*}{$\begin{array}{l}\text { Madrid Stock } \\
\text { Exchange }\end{array}$} & $-0.000 *$ & \multirow{2}{*}{$\begin{array}{l}\text { Log Madrid } \\
\text { Stock Exchange }\end{array}$} & $0.011 *$ & \multirow{2}{*}{$\begin{array}{l}\text { Log Madrid Stock } \\
\text { Exchange Index }\end{array}$} & $0.014^{*}$ \\
\hline & $(0.257)$ & & $-0.000^{*}$ & & $(0.006)$ & & $(0.008)$ \\
\hline \multirow{2}{*}{ Unemployment rate } & $1.083 * * *$ & \multirow{2}{*}{$\begin{array}{l}\text { Credit to other } \\
\text { resident sectors }\end{array}$} & $-1.093 * *$ & \multirow{2}{*}{$\begin{array}{l}\text { Credit to other } \\
\text { resident sectors }\end{array}$} & $-0.132 * * *$ & \multirow{2}{*}{$\begin{array}{l}\text { Credit to other } \\
\text { resident sectors^2 }\end{array}$} & 0.001 \\
\hline & $(0.149)$ & & $(0.398)$ & & $(0.040)$ & & $(0.061)$ \\
\hline \multirow{2}{*}{$\begin{array}{l}\text { Exchange rate } \\
\text { against USD }\end{array}$} & 0.024 & \multirow{2}{*}{$\begin{array}{l}\text { Euribor, } 12 \\
\text { months }\end{array}$} & -1.099 & Euribor, 12 & $-0.325 * *$ & & -1.507 \\
\hline & $(0.0308)$ & & $(0.791)$ & months & $(0.125)$ & 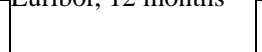 & $(0.125)$ \\
\hline Madrid Stock & 0.019 & Honc novicos & 0.326 & I & $-0.381 * * *$ & I & $-0.317 * * *$ \\
\hline Exchange Index & $(0.015)$ & nouse prices & $(0.227)$ & Log nouse price & $(0.016)$ & Log House phices & $(0.020)$ \\
\hline Credit to & 0.179 & Exchange rate & -0.002 & Exchange rate & $-0.036 * * *$ & Exchange rate against & $-0.051 *$ \\
\hline Non-financial firms & $(0.108)$ & against USD & $(0.096)$ & against USD & $(0.116)$ & USD & $(0.026)$ \\
\hline Crodit to Hound & 0.319 & SAPEP & $-0.025 * *$ & SAPEP & $-0.013 * * *$ & & \\
\hline 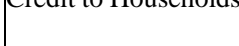 & $(0.187)$ & DAKLD & $(0.016)$ & DAKLD & $(0.002)$ & & \\
\hline & -0.453 & & & & & & \\
\hline $\begin{array}{l}\text { Spanish debt, } 10 \\
\text { years, }\end{array}$ & $(0.401)$ & & & & & & \\
\hline & $5.297 * * *$ & & & & & & \\
\hline 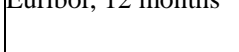 & $(1.087)$ & & & & & & \\
\hline Furibor 3 monthe & $-4.598 * * *$ & & & & & & \\
\hline Euribor, 3 months & $(1.214)$ & & & & & & \\
\hline Hence anices & -0.240 & & & & & & \\
\hline Hivuse pilues & $(0.207)$ & & & & & & \\
\hline
\end{tabular}




\begin{tabular}{|c|c|c|c|c|c|c|c|}
\hline \multirow{2}{*}{ Land prices } & 0.023 & \multirow[b]{3}{*}{ Adjusted R-s } & \multirow[b]{3}{*}{0.843} & \multirow[b]{3}{*}{ Adjusted R-s } & \multirow[b]{3}{*}{0.996} & \multirow[b]{3}{*}{ Adjusted R-squared } & \multirow[b]{3}{*}{0.956} \\
\hline & $(0.025)$ & & & & & & \\
\hline Adjusted R-squared & 0.97403 & & & & & & \\
\hline Sum squared resid & 0.000758 & S.S.R & 0.006 & S.S.R & 0.000 & Sum squared resid & 0.003 \\
\hline Akaike info criterion & $n-6.812636$ & Akaike & -5.062 & Akaike & -8.687 & Akaike info criterion & -6.538 \\
\hline Durbin-Watson stat & 2.153941 & D.W. & 0.971 & D.W.t & 2.089 & Durbin-Watson stat & 0.888 \\
\hline Log likelihood & 120.5959 & Log likelihood & 88.455 & Log likelihood & 144.645 & Log likelihood & 198.425 \\
\hline F-statistic & $81.370^{* * *}$ & F-statistic & $18.848^{* * *}$ & F-statistic & $792.612 * * *$ & F-statistic & $158.657 * * *$ \\
\hline Own elabora & ation. Calcu & ations made us & EViews, & Release 7. Depen & variable: $N$ & Ls, Standard deviatic & brackets \\
\hline & $* *$, and $* * *$ & lote signific & at level & $0 \%, 5 \%$ and $1 \%$ & pectively. D & V: Durbin-Watson sta & \\
\hline & & White hetero & skedasticity- & consistent stand & errors and co & variance & \\
\hline & Sam & ple (adjusted): 2 & $006 \mathrm{Q} 4-201$ & 14Q2 & & Sample: 200 & 2014Q2 \\
\hline & Include & d observations: & 31 after adju & istments & & Included obs & ations: 58 \\
\hline
\end{tabular}

Table 3 shows four completed models of econometric regressions. Model 1 was formed using all of the variables used in Oliver Wyman's Spanish stress tests. In this model there are problems with redundancy of the variables, the correlation between variables and the specification of the functional form. Model 2 was estimated eliminating problems with correlation and redundant variables. However the problem of the specification of the functional form remained. In order to resolve this, the two explanatory variables were modified by making logarithms in house prices and the Madrid stock exchange index.

The result is model 3 which is shown in Table 3. It confirms that the adjusted R-squared is the highest of all, at 0.995. The Sum squared resid is the lowest of all at 0.000161 . The Akaike info criterion at -8.687 confirms that model 3 is the best model. Finally the F-statistic is the greatest meaning that the model has a good global significance.

Moreover, as was seen in section 3 - materials and methods, there is no problem with validation of the model. Lastly, Table 4 shows the Standardized Coefficient and Elasticity at Means of the explanatory variables.

Table 4. Standardized Coefficient and Elasticity at Means

\begin{tabular}{cccc}
\hline Variable & Coefficient & Standardized Coefficient & Elasticity at Means \\
\hline C & 2.456948 & NA & 39.02239 \\
GDP per capita & 0.0000158 & 0.230500 & 5.683394 \\
GDP deflator & 0.000278 & 0.022702 & -0.008218 \\
Unemployment rate variation & 0.029248 & 0.097550 & 0.055096 \\
Log Madrid Stock Exchange Index & 0.011433 & 0.059167 & 1.676974 \\
Credit to other resident sectors & -0.132268 & -0.079246 & -0.00113 \\
Euribor, 12 months & -0.325474 & -0.126161 & -0.112425 \\
Log House prices & -0.380953 & -1.123205 & -45.30084 \\
Exchange rate against USD & -0.036266 & -0.038154 & -0.001794 \\
SAREB & -0.013121 & -0.076695 & -0.013444 \\
\hline
\end{tabular}

Own elaboration

\subsection{Analysis of Model 3 Results}

The first variable which appears is the unemployment rate variation; the coefficient is 0.029248 and statistically significant. Meaning that when the rate of unemployment is increased by $1 \%$ compared to the previous year the NPLs increase by 0.03 percentage points.

Another of the variables which most impacts NPLs is the price of housing. In Spain the guarantee in a mortgage loan is the very building and also any of the borrower's possessions, both current and future (Payment in lieu is not authorized as it is in some countries). House prices measures by their logarithm emerge as an important and statistically significant variable, as well as having a very high elasticity. An increase in house prices decreases NPLs by a significant amount and vice versa. 
The coefficient in the logarithm is -0.380953 . There is also an inverse relationship between the exchange rate against variation in the USD and NPLs, in this case the coefficient is -0.036 .

The increase of credit decreases NPLs, and so the coefficient of regression decreases - 0.132 . At least in stages such as those covered by this investigation. This inverse relationship is can also be observed between the Euribor at 12 months and the NPLs. In this case the regression coefficient is -0.325 . The coefficient obtained in the regression for the Madrid stock Exchange is positive, 0.011 and also statistically significant at a level of $10 \%$.

The dummy variable, named SAREB, which identifies the assignment of "toxic assets" in the final quarter of 2012 and the first quarter of 2013 is also statistically significant. The coefficient is -0.013 which confirms the reduction in default for the transfer of assets with high NPLs to SAREB.

The last variable studied is the GDP per capita. This variable substitutes the real GDP and the nominal GDP. This change is motivated by the correlation which exists between the variables the real GDP and the nominal GDP and between these and various other explanatory variables. GDP is a variable which incorporates the effects on NPLs of many of the variables used for Oliver Wyman's report (Wyman 2012). It is also the variable which best represents the personal wealth of each citizen. GDP can decrease, but if the population is reduced by a small proportion the wealth of citizens will not be affected and, therefore, neither will the NPLs be affected.

The coefficient is 0.0000158 , ie practically zero. Although the coefficient is very small, the normalized coefficient and elasticity are quite large.

\section{Conclusions and Discussion}

According to Til Schuermann (Schuermann, 2014) the stress tests can provide transparency to the financial system which would allow for increased reliability. The investigator confirms that standard approaches such as coefficients of regulatory capital ratio are no longer credible. On the other hand he claims that bank balances are notoriously opaque and susceptible to the substitution of high risk assets from low risk assets.

Using this premise this article provides more clarity to stress tests. Stress tests estimate both decline and profit according to the assets of credit companies and the predictions from macroeconomic scenarios. However, they do not provide information which links these two variables. This means that the coefficients are applied between the scenarios and the assets in order to obtain distinct estimations.

The increase in literature on the topic is overwhelmingly justified. Stress tests sometimes fail and when they do fail the results can be transcendental, e.g. the Bankia case. Bankia had the support of stress tests from the EBA and in less than one year after their publication it needed an injection of public funds of more than 22,500 million euros.

In this paper a model by means of multiple lineal regressions to estimate the aforementioned parameters to evaluate the NPLs of credit entities is estimated.

Firstly the variables used in the stress tests in the report by Oliver Wyman (Wyman 2012) are studied. Whether or not all variables are necessary is studied. Of the 14 variables used in the two scenarios 6 are eliminated for being redundant and are modified in order to validate the econometric model.

Of the 8 variables used to construct the model four had a negative coefficient and therefore their increase decreases delinquency, they are: credit to other resident sectors, exchange rate against USD, log house prices and Euribor 12 months. Three variables had a positive coefficient and therefore an increase in these variables increases delinquency, they are: GDP per capita, unemployment rate variation and log Madrid stock exchange index. The GDP deflator resulted statistically insignificant. Furthermore a dummy variable was included in order to detect the creation of the SAREB, this resulted statistically significant and with a negative sign.

Once estimated the model was contrasted in order to test whether or not it continues to be valid when the duration of the sample is increased. The number of years included in the sample was increased from 7.5 to 15 and the result was that the model ceased to give a correct specification according to the Ramsey Reset Test. Three variables ceased to be statistically significant and moreover a structural change appeared in the fourth trimester of 2006, contrasted by means of the Chow Breakpoint Test and the Chow Forecast Test.

A high number of variables in the scenarios do not improve the results of the predictions. Many of the variables are redundant; they provide similar information and produce a worsening of the predictions. This is one of the contributions of the literature review to the stress test.

Another aspect which should be taken into account is the choice of variables. Some variables are conditioned by other factors already contemplated in the model and can worsen the predictions. E.g. in the real GDP and the nominal GDP the two following characteristics can be observed. 1) they are redundant seeing as in the scenarios the deflator GDP and the harmonized index of consumer prices are also incorporated. 2) the nominal GDP is the sum of the real GDP and one 
of the two previous variables. In Spain from the second trimester of 2013 to the second trimester of 2014 the GDP per capita has increased, whilst the real GDP and nominal GDP have decreased. This situation occurs as a result of two factors. i) the population loss was greater in relative terms than the reduction of the real GDP and ii) in this period Spain had a very low GDP deflator and harmonized index of consumer prices, in some periods it was even negative.

Each scenario should have different coefficients. The economy does not affect the assets of credit institutions in the same way in the same scenarios, which is proven in model 4 . The coefficients validated for the period 2006q4 to $2014 \mathrm{q} 2$ are not valid for the period 2000q1 to 2006q3.

An attempt was made to obtain information about which coefficients were used in the September 2012 report by Oliver Wyman from the Banco de España, but we were referred to Oliver Wyman given that, according to the BdE it was he who used them. Oliver Wyman was contacted in various manners but no answer has been received.

The objective for this information was to contrast it with the obtained information by use of regressions and to obtain conclusions in order to improve to forecast of the stress tests

The paper contributes two improvements to the literature a)an improvement in the interpretation and construction of stress tests by means of econometric analysis and b) it proves that the influence of the parameters changes for each stage of the crisis with respect to growth. Therefore, for each stage of the economy it is necessary to estimate different econometric models. Applying the same parameters to a base scenario as to an adverse scenario is not valid. The intensity with which the same variable, for example unemployment affects the NPLs, is different in times of recession, compared to times of growth. Usually the impact is greater in times of recession.

\section{Acknowledgements}

The author wish to thank Claire Harrison for translating into English the text of the paper.

\section{References}

Abdymomunov, A., \& Gerlach, J. (2014). Stress testing interest rate risk exposure. Journal of Banking and Finance 49, 287-301. http://dx.doi.org/10.1016/j.jbankfin.2014.08.013

Alessi, L., Ghysels, E., Onorante, L., Peach, R., \& Potter, S. (2014). Central Bank Macroeconomic Forecasting During the Global Financial Crisis: The European Central Bank and Federal Reserve Bank of New York Experiences, Journal of Business and Economic Statistics, 32(4), 483-500. http://dx.doi.org/10.1080/07350015.2014.959124

Asmild, M., \& Matthews, K. (2012). Multi-directional efficiency analysis of efficiency patterns in Chinese banks 19972008. European Journal of Operational Research, 219, 434-441. http://dx.doi.org/10.1016/j.ejor.2012.01.001

Barr, R., \& Siems, T. (1994). Predicting bank failure using DEA to quantify management quality. Federal Reserve Bank of Dallas. Financial Industry Studies Working Paper, 1-94.

Basu, S. (2013). Comparing simulation models for market risk stress testing. European Journal of Operational Research, 213, 329-339. http://dx.doi.org/10.1016/j.ejor.2011.02.023

Bellini, T. (2013). Integrated bank risk modeling: A bottom-up statistical framework. European Journal of Operational Research, 230(2), 385-398. http://dx.doi.org/10.1016/j.ejor.2013.04.031

Berger, A. N., \& DeYoung, R. (1997). Problem loans and cost efficiency in commercial banks. Journal of Banking and Finance, 21(6), 849-870. http://dx.doi.org/10.1016/S0378-4266(97)00003-4

Berger, R. (2012). Stress Testing Spanish Banks. Final Report. http://goo.gl/4ry2Mo

Board of Governors of the Federal Reserve System (2009). The Supervisory Capital Assessment Program: Overview of Results. http://goo.gl/uVNpO0

Boran, G. (2011). Credit Risk Management, Journal of Applied Statistics, 38(6), 1314-1314, http://dx.doi.org/10.1080/02664760903335083

Buncic, D., \& Melecky, M. (2013). Macroprudential stress testing of credit risk: A practical approach for policy makers. Journal of Financial Stability, 9, 347-370. http://dx.doi.org/10.1016/j.jfs.2012.11.003

Buraschi, A., Menguturk, M., \& Sener, E. (2014). The geography of funding markets and limits to arbitrage. Review of Financial Studies, 28(4), 1103-1052. http://dx.doi.org/10.1093/rfs/hhu090

CEBS. (2010). Aggregate outcome of the 2010 EU wide stress test exercise coordinated by CEBS in cooperation with the ECB. http://goo.gl/pJK2op

Cerutti, E., \& Schmieder. C. (2014). Ring fencing and consolidated banks' stress tests. Journal of Financial Stability, 11, 1-12. http://dx.doi.org/10.1016/j.jfs.2013.10.003

Čihák, M., (2007). Introduction to Applied Stress Testing. IMF Working Paper No.07/59. International Monetary Fund. 
http://goo.gl/4QZ6mN

Climent, S. S., \& Pavía, J. M. (2014a). An analysis of loan default determinants: The Spanish case. Banks and Bank systems, 9(4), 114-121. http://goo.gl/1kj7zb

Climent, S. S., \& Pavía, J. M. (2014b). Determinantes y diferencias en la rentabilidad de cajas y bancos. Revista de Economía Aplicada, 65(XXII), 117-154. http://goo.gl/dfSkqi

Climent, S. S., \& Pavía, J. M. (2015). Bankia: para qué sirven los estados contables y los órganos de control. Estudios de economía aplicada. 33-1, 1-42. http://goo.gl/2zO4r3

Coffinet, J., Pop, A., \& Tiesset, M. (2013). Monitoring financial distress in a high-stress financial world: The role of option prices as bank risk metrics. Journal of Financial Services Research, 44(3), 229-257. http://dx.doi.org/10.1007/s10693-012-0150-2

Das, A., \& Ghosh, S. (2004). Non-performing loan, capital and productivity change: evidence from Indian state-owned banks. Global Journal of Finance and Economics, 1, 35-58.

Demirguc-Kunt, A. (1989). Deposit-institution failures: A review of the empirical literature. Federal Reserve Bank of Cleveland, Economic Review, Quarter 4. http://goo.gl/T2DhDu

EBA (European Banking Authority) (2011). EU-Wide Stress Test Aggregate Report. http://goo.gl/VAQAwj

Festić, M., Kavkler, A., \& Repina, S. (2011). The macroeconomic sources of systemic risk in the banking sectors of five new EU member states. Journal of Banking and Finance, 35(2), 310-322. http://dx.doi.org/10.1016/j.jbankfin.2010.08.007

Foglia, A. (2009). Stress testing credit risk: a survey of authorities' approaches. International Journal of Central Banking, 5(3), 9-45. http://goo.gl/R7hAUD

Ghosh, S. (2005). Does leverage influence banks' non-performing loans? Evidence from India, Applied Economics Letters, 12(15) 913-918, http://dx.doi.org/10.1080/13504850500378064.

Gutiérrez, L. J., \& Abad, G. (2014) ¿Permitían los estados financieros predecir los resultados de los tests de estrés de la banca española? Una aplicación del modelo logit. Revista de Contabilidad - Spanish Accounting Review, 17(1), 58-70. http://dx.doi.org/10.1016/j.rcsar.2013.08.004

Huang, X., Zhou, H., \& Zhu, H. (2009). A framework for assessing the systemic risk of major financial institutions. Journal of Banking and Finance, 33, 2036-2049. http://dx.doi.org/10.1016/j.jbankfin.2009.05.017

International Monetary Fund (2012) Spain: Financial Stability Assessment. IMF Country Report No. 12/137. http://www.imf.org/external/pubs/ft/scr/2012/cr12137.pdf

Jakubik, P. (2007). Macroeconomic environment and credit risk. Czech Journal of Economics and Finance, 57(1-2), 60-78. http://goo.gl/fSQTER

Ju, Y., Jeon, S. Y., \& Sohn, S. Y. (2015). Behavioral technology credit scoring model with time-dependent covariates for stress test. European Journal of Operational Research, 242(3), 910-919. http://dx.doi.org/10.1016/j.ejor.2014.10.054

Kwan, S., \& Eisenbis, R. A. (1997) Bank risk, capitalization and operating efficiency. Journal of Financial Services Research, 12, 117-31. DOI 10.1023/A:1007970618648

Pérez-Cárceles, M. C., Gómez-Gallego, J. C., \& Gómez-García, J. (2016). Distribution of cost inefficiency in stochastic frontier approach: evidence from Spanish banking. Journal of Applied Statistics, 1-12. http://dx.doi.org/10.1080/02664763.2016.1161737

Podpiera, J., \& Weill, L. (2008). Bad luck or bad management? Emerging banking market experience. Journal of Financial Stability, 4, 135-148. http://dx.doi.org/10.1016/j.jfs.2008.01.005

Rajan, R. J., \& Zingales, L. (1995). What do we know about capital structure? Some evidence from international data. Journal of Finance. 50, 1421-60. http://dx.doi.org/10.1111/j.1540-6261.1995.tb05184.x

Rime, B. (2001). Capital requirements and bank behaviour: empirical evidence for Switzerland. Journal of Banking and Finance, 25, 789-805. http://dx.doi.org/10.1016/S0378-4266(00)00105-9

Schuermann, T. (2014) Stress testing banks. International. Journal of Forecasting, 30, 717-728. http://dx.doi.org/10.1016/j.ijforecast.2013.10.003

Sorge, M. (2004). Stress Testing Financial Systems: An Overview of Current Methodologies. BIS Working Paper No. 165. Bank for International Settlements. http://goo.gl/2fhh8c 
Wang, M. H., \& Huang, T. H (2007). A study on the persistence of Farrell's efficiency measure under a dynamic framework. European Journal of Operational Research, 180, 1302-1316. http://dx.doi.org/10.1016/j.ejor.2006.04.043

Whalen, G. (1991). A proportional hazards model of bank failure: An examination of its usefulness as an early warning tool. Federal Reserve Bank of Cleveland, Economic Review. Quarter 1. https://core.ac.uk/download/files/153/6230075.pdf

Wyman, O. (2012). Asset quality review and bottom-up stress test exercise. Banco de España. http://goo.gl/3OvUAp

\section{Copyrights}

Copyright for this article is retained by the author(s), with first publication rights granted to the journal.

This is an open-access article distributed under the terms and conditions of the Creative Commons Attribution license which permits unrestricted use, distribution, and reproduction in any medium, provided the original work is properly cited. 